Rev. Int. Contam. Ambie. 34 (3) 417-425, 2018

DOI: 10.20937/RICA.2018.34.03.05

\title{
REMOVAL OF TOLUENE FROM TWO CONTRASTING SOILS, AN AGRICULTURAL SOIL AND AN ALKALINE SOIL
}

\author{
Benito José GONZÁLEZ-BOURGUET ${ }^{1}$, Víctor Manuel RUÍZ-VALDIVIEZO*, \\ Mario HERNÁNDEZ-GUZMÁN ${ }^{2}$, Laura DELGADO-BALBUENA ${ }^{1}$, \\ Marco LUNA-GUIDO ${ }^{1}$ and Luc DENDOOVEN ${ }^{1}$
}

${ }^{1}$ Laboratorio de Ecología del Suelo, Centro de Investigación y de Estudios Avanzados, Instituto Politécnico Nacional. Avenida Instituto Politécnico Nacional 2508, Colonia San Pedro Zacatenco, Delegación Gustavo A. Madero, Ciudad de México, México, C. P. 07360

${ }^{2}$ Laboratorio de Biología Molecular, Departamento de Ingeniería Química y Bioquímica, Instituto Tecnológico de Tuxtla Gutiérrez, Tecnológico Nacional de México. Carretera Panamericana kilómetro 1080, Apartado Postal 599, Tuxtla Gutiérrez, Chiapas, México. C. P. 29050

*Corresponding author: bioqvic@hotmail.com

(Received January 2017; accepted October 2017)

Key words: dynamics, contamination, emissions, clay, silt, dissipation

\begin{abstract}
Among the most serious environmental disasters that threaten biodiversity in soil are oil spills. Different factors control the removal of hydrocarbons from soil, e.g., soil characteristics, composition of the contaminant, and the composition of the microbial population. Toluene is highly volatile, toxic and soluble in water so its removal from soil is important to limit the damage to the environment. Two soils, an arable soil from Otumba, State of Mexico, Mexico, and an alkaline soil from the former Texcoco lakebed, were spiked with three concentrations of toluene $\left(\mathrm{C}_{7} \mathrm{H}_{8}\right)$ and incubated aerobically for 20 days. The $\mathrm{CO}_{2}$ emission and the contaminant in the headspace of the microcosm and the soil were monitored. The $\mathrm{CO}_{2}$ emission increased with increased application of toluene, but showed a lag of two days. After one day, volatilization of toluene was substantial from both soils, $34 \%$ from the Texcoco soil and $58 \%$ from the Otumba soil, but most of it was removed from the headspace within two days. Overall, $98 \%$ of the toluene added to soil was recovered. No abiotic factor affected the removal of toluene from soil. Nearly all toluene was removed from the Texcoco soil within one day independent of the amount applied, but it took more than three days in the arable soil. A lag of two days between dissipation and mineralization was detected, as toluene first has to be incorporated in the microbial cell before it can be degraded. The removal of toluene was faster from the Texcoco soil than from the arable soil.
\end{abstract}

Palabras clave: dinámicas, contaminación, emisión, arcilla, limo, disipación 


\section{RESUMEN}

Entre los desastres ambientales más graves que amenazan a la biodiversidad se encuentran los derrames de hidrocarburos en ríos, mares, océanos y el suelo. Diferentes factores controlan la eliminación de hidrocarburos del suelo, es decir, las propiedades del suelo, las características y composición del contaminante y la composición de la población microbiana. El tolueno es altamente volátil, tóxico y soluble en agua, por lo que su eliminación del suelo es importante para limitar los daños al ambiente. Se utilizaron dos suelos del Estado de México, un suelo agrícola de Otumba y un suelo alcalino del antiguo lecho del lago de Texcoco, los que fueron contaminados con tres concentraciones de tolueno y se incubaron aeróbicamente durante 20 días. Se monitoreó la emisión de $\mathrm{CO}_{2}$ y el contaminante en el espacio poroso del suelo. $\mathrm{La}$ emisión de $\mathrm{CO}_{2}$ aumentó cuando la aplicación del tolueno fue mayor, pero esto se observó después de dos días. La volatilización del tolueno fue sustancial en ambos suelos, es decir, $34 \%$ en el suelo de Texcoco y $58 \%$ en el suelo de Otumba, pero la mayor parte del tolueno se removió del espacio poroso en dos días. En general, se recuperó el $98 \%$ del tolueno añadido al suelo. Ningún factor abiótico afectó la eliminación del tolueno del suelo. Casi todo el tolueno se retiró del suelo de Texcoco en un día, independientemente de la cantidad aplicada, pero tardó más de tres días en el agrícola. El tolueno se removió rápidamente del suelo y ningún factor abiótico afectó su concentración. Se observó un retraso de dos días entre la disipación y la mineralización del tolueno, ya que primero tuvo que ser incorporado en la célula microbiana antes de ser degradado. La remoción del tolueno fue más rápida en el suelo de Texcoco que en el suelo agrícola.

\section{INTRODUCTION}

Soil contamination with polycyclic aromatic hydrocarbons does not only affect soil processes, but might damage a whole ecosystem as the pollutant might end up in rivers, ground water and aquifers (Shaheen et al. 2014). In 2015, the Mexican inventory of contaminated sites by oily sludges, solid wastes (tows, batteries, paints, cleaning plants, etc.) and spent caustic sodas were about 1161.93 ha (PEMEX 2016). Oil and its derived products contain aromatic hydrocarbons, such as benzene, toluene, ethylbenzene and xylenes (BTEX). These compounds might cause cell damage, cancer and leukemia and they are genotoxic and neurotoxic (Deziel et al. 2014, Gui-Zhen et al. 2015). Toluene is especially hazardous for the environment and humans as it is toxic and its solubility in water might pose a human health risk (Daghio et al. 2016).

The rate of removal of toluene from soil is important so as to limit the damage to the environment. Autochthonous soil microorganisms are known to degrade toluene. For instance, Jindrova et al. (2002) reported that bacteria, such as Pseudomonas sp., $P$. mendocina KRI, P. paucimobilis and Burkholderia cepacia $\mathrm{G} 4$, contribute to the degradation of BTEX in a gasoline-contaminated soil and groundwater.
Zhang et al. (2013), using ${ }^{14} \mathrm{C}$-labeled toluene, found that phylotypes belonging to Paenibacillus, Microbacterium, Rhodococcus mineralized 43 to $49 \%$ of it, confirming their ability to metabolize this compound. While Yadav et al. (2012) and Zhang and Bouwer (1997), reported between $98 \%$ and a complete degradation of toluene respectively.

In pre-Hispanic times the lakes that surrounded Tenochtitlan (now Mexico City) covered $2000 \mathrm{~km}^{2}$. Lake Texcoco, the largest of those lakes, covered $1000 \mathrm{~km}^{2}$ and was divided by dikes so that brackish and freshwater were kept separated. From the $17^{\text {th }}$ century onwards, the original lakes were drained to prevent flooding of Mexico City (Luna-Guido et al. 2003). The former lakebed is alkaline saline $(\mathrm{pH}$ 9-10.5 and sometimes EC $>100 \mathrm{dS} / \mathrm{m})$ and a drainage system has been installed to wash the salts from the soil. In the 70s, the Comisión Nacional de Agua (CNA, the Mexican national water commission) started a program of drainage of saline soils and to establish vegetation. The most saline parts were flooded with effluents from a nearby treatment plant, decreasing salinity for several years, achieving near normal soil conditions and in reducing the salt content and $\mathrm{pH}$ substantially from electrolytic conductivity $(\mathrm{EC})>50 \mathrm{dS} / \mathrm{m}$ and $\mathrm{pH}>10$ to $\mathrm{EC}<$ 
$10 \mathrm{dS} / \mathrm{m}$ and $\mathrm{pH}<8.5$ (Luna-Guido et al. 2000). A unique ecosystem has been formed that allows to study how soil processes respond to high alkalinity. It can be speculated (Fernández-Luqueño et al. 2016) that degradation of hydrocarbons might be different in an alkaline soil with a high organic matter content than a more neutral arable soil with a low organic matter content.

As part of the study into the removal of hydrocarbons from soil, an arable soil and an alkaline soil were collected at two locations: Otumba and the former Lake Texcoco, respectively, both in the State of Mexico (Mexico). The two soils were contaminated with three different concentrations of toluene $(100,200$ or $500 \mathrm{mg} / \mathrm{kg}$ ), while dynamics of toluene were monitored in the soil and the headspace of the $120 \mathrm{~cm}^{3}$ glass flasks for 20 days. The objective of this study was to investigate the removal of toluene from two contrasting soils.

\section{MATERIALS AND METHODS}

Soil was collected from the $0-15 \mathrm{~cm}$ layer of two different locations in State of Mexico (Mexico). A first sampling site was located in the former Lake Texcoco in the Valley of Mexico City. The details of the sampling site and soil characteristics can be found in Dendooven et al. (2010). The sampling site is located in a drained part of the former lake Texcoco, which lies at an altitude of 2240 masl $\left(19^{\circ} 30^{\prime} 48.00^{\prime \prime} \mathrm{N}\right.$ - 98 $\left.59^{\prime} 25.14^{\prime \prime} \mathrm{W}\right)$. The site was not contaminated with hydrocarbons upon sampling and is flooded irregularly with sewage effluent that might contain hydrocarbons. The mean annual temperature at the sampling site is $16^{\circ} \mathrm{C}$ with a mean annual precipitation of $705 \mathrm{~mm}$ mostly from June until October. The $\mathrm{pH}$ in the saturated soil extract was 8.3, particle size distribution in the loamy sand soil was clay $96 \mathrm{~g} / \mathrm{kg}$, silt $93 \mathrm{~g} / \mathrm{kg}$ and sand $811 \mathrm{~g} / \mathrm{kg}$, the electrolytic conductivity (EC) $2.68 \mathrm{dS} / \mathrm{m}$, the water holding capacity (WHC) $860 \mathrm{~g} / \mathrm{kg}$ and the organic carbon content of $48 \mathrm{~g} / \mathrm{kg}$ all on a dry matter base.

The second sampling site was located in Otumba, State of Mexico (194 $\left.41^{\prime} 23.52^{\prime \prime} \mathrm{N}-98^{\circ} 43^{\prime} 14.28^{\prime \prime} \mathrm{W}\right)$. The details of the sampling site and soil characteristics can be found in Aguilar-Chávez et al. (2012). Briefly, its average altitude is 2349 masl and characterized by a sub-humid temperate climate with a mean annual temperature of $14.8{ }^{\circ} \mathrm{C}$ and average annual precipitation of $577 \mathrm{~mm}$ mainly from June through August. The area is mainly cultivated with maize and common bean, receiving a minimum amount of inorganic fertilizer without being irrigated. The $\mathrm{pH}$ in the saturated soil extract was 7.6 and the particle size distribution in the loamy sand soil was clay $90 \mathrm{~g} / \mathrm{kg}$, silt $40 \mathrm{~g} / \mathrm{kg}$ and sand $870 \mathrm{~g} / \mathrm{kg}$. The EC in the soil extract was $1.15 \mathrm{dS} / \mathrm{m}$, the WHC $650 \mathrm{~g} / \mathrm{kg}$ and the organic carbon content $6.3 \mathrm{~g} / \mathrm{kg}$ all on a dry matter base. The field based replication (three soil samples from both sites) was maintained in the laboratory experiment.

The soil (560 g of each soil) was adjusted to $40 \%$ of WHC and pre-incubated separately for 7 days in a drum containing a beaker with $100 \mathrm{~mL}$ of water to avoid desiccation and one beaker with $100 \mathrm{~mL}$ of $1 \mathrm{M}$ $\mathrm{NaOH}$ solution to trap $\mathrm{CO}_{2}$ evolved. Seven different treatments were applied to the six soil samples, i.e. three from Otumba and three from Texcoco. Sterilized and unsterilized soil was amended with 100, 200 or $500 \mathrm{mg} \mathrm{C}_{7} \mathrm{H}_{8} / \mathrm{kg}$ dry soil, while unsterilized and unamended soil samples served as control.

Forty-two subsamples of $10 \mathrm{~g}$ of each soil $(\mathrm{n}=2)$ and replicate $(\mathrm{n}=3)$ were added separately to $120 \mathrm{~cm}^{3}$ glass flasks. Half of the subsamples were first sterilized for three consecutive days at $120^{\circ} \mathrm{C}$ for $30 \mathrm{~min}$. Seven subsamples of the sterilized and unsterilized soil of each soil and replicate were amended with 100 $\mathrm{mg} \mathrm{C}_{7} \mathrm{H}_{8} / \mathrm{kg}$ dry soil (equivalent to $91.25 \mathrm{mg} \mathrm{C} / \mathrm{kg}$ dry soil), $200 \mathrm{mg} \mathrm{C}_{7} \mathrm{H}_{8} / \mathrm{kg}$ dry soil (equivalent to $182.5 \mathrm{mg} \mathrm{C} / \mathrm{kg}$ dry soil) or $500 \mathrm{mg} \mathrm{C}_{7} \mathrm{H}_{8} / \mathrm{kg}$ dry soil (equivalent to $456.25 \mathrm{mg} \mathrm{C} / \mathrm{kg}$ dry soil). Seven samples of each soil $(n=2)$ and replicates $(n=3)$ were left unamended and served as control. A $2 \mathrm{~cm}^{3}$ vial containing $1 \mathrm{~cm}^{3} 2 \mathrm{M} \mathrm{NaOH}$ was placed in the flasks and the flasks were stoppered airtight. After 0 , $1,2,3,6,10$ and 20 days, three flasks from each treatment (a flask from each soil sample) were selected at random. The headspace was analyzed for toluene on a gas chromatograph, the flasks were opened, the vial with $\mathrm{NaOH}$ removed and the $\mathrm{CO}_{2}$ trapped was quantified by automatic titration with $0.1 \mathrm{M} \mathrm{HCl}$ on an auto-titration system Metrohm SM 702 Titrino (Herisau, Switzerland) (Jenkinson and Powlson 1976a). The soil was removed from the flasks and extracted for toluene as described below.

The soil samples were analyzed for particle size distribution by the hydrometer method (Gee and Bauder 1986). While total organic carbon was measured with a total organic carbon analyzer TOCVCSN (Shimadzu, Canby, USA). Total nitrogen (N) was measured by the Kjeldahl method using a digestion made with concentrated $\mathrm{H}_{2} \mathrm{SO}_{4}, \mathrm{~K}_{2} \mathrm{SO}_{4}$ and $\mathrm{HgO}$ to digest the sample and the solution is then distilled, which converts the ammonium salt to ammonia. The amount of nitrogen present in the sample is deter- 
mined by back titration (Bremner 1996). The water holding capacity (WHC) was measured as described by Jenkinson and Powlson (1976b). Briefly, the WHC was determined by subtracting a given mass of a dry soil sample from the mass of the same saturated with water, left to drain overnight throughWhatman No. 42 filter paper and covered with aluminum foil to avoid evaporation. The EC was measured in a saturated solution extract and $\mathrm{pH}$ in $1: 2.5$ soil- $\mathrm{H}_{2} \mathrm{O}$ suspension using a glass electrode. The toluene concentration in the soil was determined by a modified technique as described by Song et al. (1995). Briefly, $1 \mathrm{~g}$ soil was added to a Pyrex tube and $5 \mathrm{~cm}^{3}$ acetone was applied. The tubes were placed in an ultrasonic bath at $25^{\circ} \mathrm{C}$ for $30 \mathrm{~min}$, mechanically shaken on a vortex for $10 \mathrm{sec}$, and sonicated again for $30 \mathrm{~min}$ at $130 \mathrm{~W}$ in a FS30H Ultrasonic Cleaner (Fisher Scientific, Suwanee, GA, USA). The extracts were separated from the soil by centrifugation at $3500 \mathrm{rpm}$ and $4{ }^{\circ} \mathrm{C}$ for $10 \mathrm{~min}$. This process was repeated twice. The extracts were combined and adjusted to $10 \mathrm{~cm}^{3}$ with acetone. The concentration of toluene in the volatile organic compounds was quantified on a flame ionization detector (FID) fitted with $15 \mathrm{~m}$ a HP-5 column, with injection temperature of $150{ }^{\circ} \mathrm{C}$, oven temperature $40{ }^{\circ} \mathrm{C}$ and detector temperature $280{ }^{\circ} \mathrm{C}$. The flow rate of He was $16.7 \mathrm{~cm}^{3} / \mathrm{min}$.

Significant differences between the emission of $\mathrm{CO}_{2}$ and concentration of toluene in the soil and the headspace as a result of the different treatments applied were determined by analysis of variance and based on the least significant difference using the general linear model procedure PROC GLM (SAS Institute 1989).

\section{RESULTS AND DISCUSSION}

In the sterilized Texcoco soil spiked with $500 \mathrm{mg}$ $\mathrm{C}_{7} \mathrm{H}_{8}$, the concentration of toluene did not change significantly over time (Fig. 1a). Approximately 310 $\mathrm{mg} \mathrm{C}_{7} \mathrm{H}_{8} / \mathrm{kg}$ dry soil was extracted from the sterilized soil applied with $500 \mathrm{mg} \mathrm{C}_{7} \mathrm{H}_{8}, 113 \mathrm{mg} \mathrm{C}_{7} \mathrm{H}_{8} / \mathrm{kg}$ dry soil when applied with $200 \mathrm{mg} \mathrm{C}_{7} \mathrm{H}_{8}$ and $60 \mathrm{mg}$ $\mathrm{C}_{7} \mathrm{H}_{8} / \mathrm{kg}$ dry soil when applied with $100 \mathrm{mg} \mathrm{C}_{7} \mathrm{H}_{8}$. In the unsterilized Texcoco soil, nearly all toluene $(<20 \mathrm{mg}$ remained) was removed within one day, independently of the amount added.

In the sterilized arable soil spiked with $500 \mathrm{mg}$ $\mathrm{C}_{7} \mathrm{H}_{8}$, the concentration of toluene did not change

b) Otumba soil
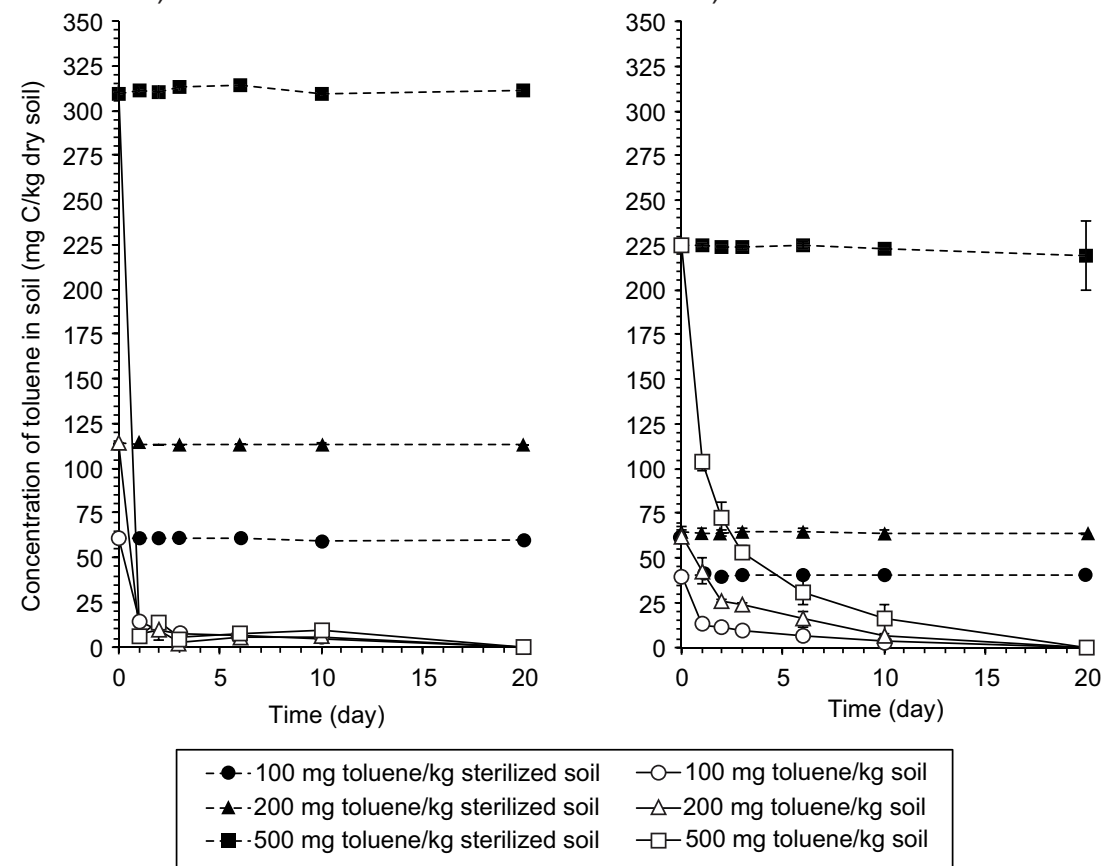

Fig. 1. Concentration of toluene ( $\mathrm{mg} \mathrm{C} / \mathrm{kg}$ dry soil) in a) sterilized or unsterilized soil of the former Lake Texcoco and (b) the Otumba soil. Sterilized soil amended with $100(\bullet), 200(\boldsymbol{\Delta})$ or $500 \mathrm{mg}$ toluene/kg dry soil (•) and unsterilized soil amended with $100(\circ), 200(\Delta)$ or $500 \mathrm{mg}$ toluene/kg dry soil $(\square)$ 
significantly over time as occurred in the Texcoco soil (Fig. 1b). Approximately $225 \mathrm{mg} \mathrm{C}_{7} \mathrm{H}_{8} / \mathrm{kg}$ dry soil was extracted from the sterilized soil applied with $500 \mathrm{mg} \mathrm{C} \mathrm{C}_{7} \mathrm{H}_{8}, 63 \mathrm{mg} \mathrm{C}_{7} \mathrm{H}_{8} / \mathrm{kg}$ dry soil when applied with $200 \mathrm{mg} \mathrm{C}_{7} \mathrm{H}_{8}$ and $40 \mathrm{mg} \mathrm{C}_{7} \mathrm{H}_{8} / \mathrm{kg}$ dry soil when applied with $100 \mathrm{mg} \mathrm{C}_{7} \mathrm{H}_{8}$. In the unsterilized arable soil, the removal of toluene was slower than in the Texcoco soil, independently of the amount added (Fig. 1a). For instance, $>100 \mathrm{mg} / \mathrm{kg}$ dry soil remained in soil amended with $500 \mathrm{mg} \mathrm{C}_{7} \mathrm{H}_{8}$ after one day. Even after 10 days, the amount of $\mathrm{C}_{7} \mathrm{H}_{8}$ extracted from soil amended with $500 \mathrm{mg}$ was still $16 \mathrm{mg} \mathrm{C}_{7} \mathrm{H}_{8} / \mathrm{kg}$ dry soil.

In this work the concentration of toluene did not change significantly over time in the sterilized soil. This indicated that no abiotic factor affected the removal of toluene from soil and sequestration of toluene was limited. Tsao et al. (1998) stated that $14 \%$ of the added $737 \mathrm{mg} \mathrm{C}_{7} \mathrm{H}_{8} / \mathrm{kg}$ was not extractable from a soil after 30 days, that is, it was sequestered. Differences in the amount of toluene extracted might be due to the length of the incubation and the extraction technique and the soil characteristics (Davis and Madsen 1996). The incubation time of the sterilized soil was short, so that the sequestration of toluene was minimal, but it can be speculated that an increased contact between the contaminant and the soil will increase the fixation of hydrocarbon on the soil matrix and thus reduce the mineralization of toluene (Yang et al. 2010a, Woods et al. 2011).

The concentration of toluene in the headspace of the sterilized arable and alkaline soil did not change significantly over time (Fig. 2a). However, the amount of toluene in the headspace of the flasks incubated with the Texcoco soil was lower than in the headspace of the arable soil. The concentration of toluene in the headspace of the Texcoco soil dropped and within 2 days nearly all toluene was removed from the headspace, independently of the amount added to soil (Fig. 2b). In the flasks with arable soil, some toluene was still detectable in the headspace after two days.

Toluene is highly volatile and a large amount of it added to soil was detected in the headspace. It can be assumed that some toluene got lost during application, some was not extracted or some got lost through the stoppers. In a separate experiment, (flasks without soil and $\mathrm{NaOH}$ ) the amount of toluene lost through the stoppers was $<1.5 \mathrm{mg} / \mathrm{kg}$. Overall, $98 \%$ of the $500 \mathrm{mg}$ toluene added to soil was recovered (sum

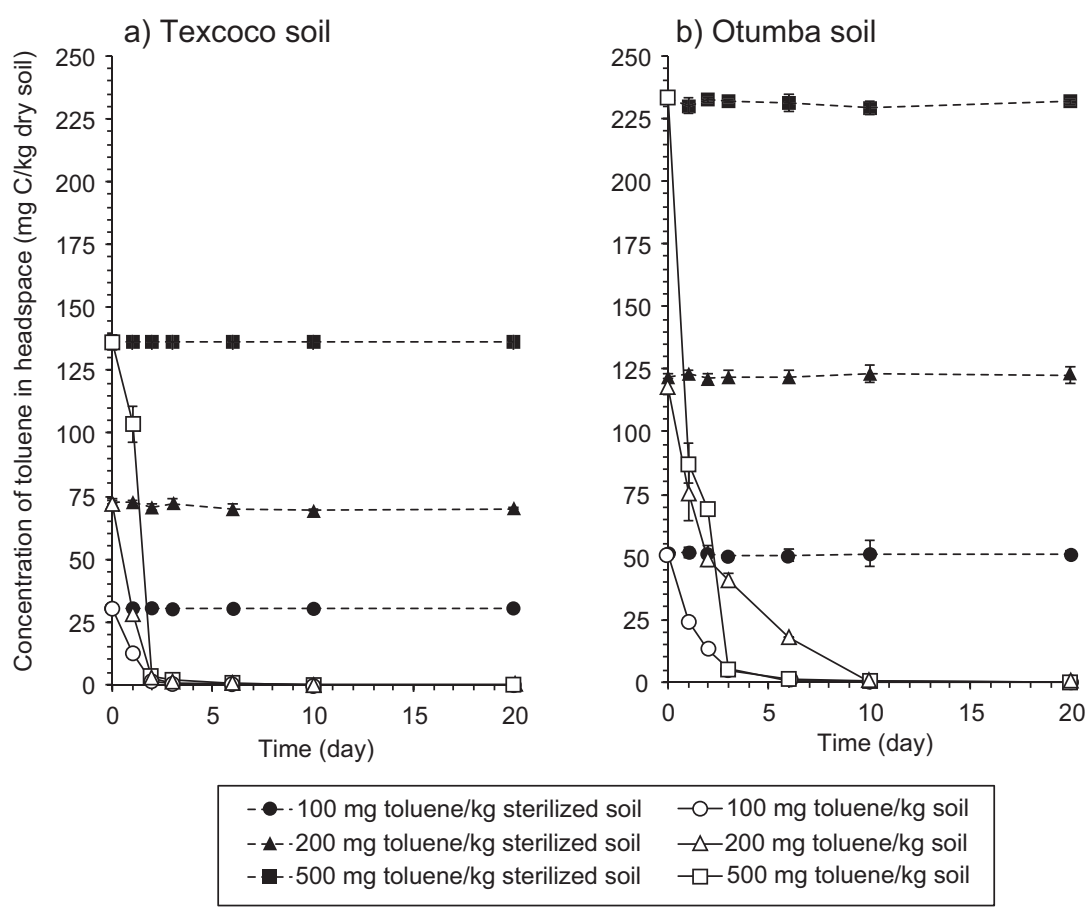

Fig. 2. Concentration of toluene ( $\mathrm{mg} \mathrm{C} / \mathrm{kg}$ dry soil) in the headspace of a) sterilized or unsterilized soil of the former Lake Texcoco and (b) the Otumba soil. Sterilized soil amended with $100(\bullet), 200(\boldsymbol{\Delta})$ or $500 \mathrm{mg}$ toluene/kg dry soil (ロ) and unsterilized soil amended with $100(\circ), 200(\Delta)$ or $500 \mathrm{mg}$ toluene/kg dry soil ( $\square$ ) 
of the toluene in the headspace and in the sterilized soil). Similar percentages were recovered when 100 or $200 \mathrm{mg}$ toluene was added to the Texcoco and the arable soil.

It is well known that soil microorganisms degrade hydrocarbons from soil and even polyaromatic hydrocarbons, such as benzo(a)pyrene, are removed from soil. Most of the toluene was removed within two days. In different studies, different removal rates of toluene from soil have been reported. Tsao et al. (1998) found that nearly $60 \%$ of ${ }^{14} \mathrm{C}$-labelled toluene added to a sandy loam soil at $0.003 \mathrm{~mL} / \mathrm{g}$ was removed from soil within 7 days and all of it within 25 days. Zhang and Bouwer (1997) reported that in pre-equilibrated soil-water slurries with $\mathrm{pH}$ ranging from 6.8 to 8 and amended with $200 \mathrm{mg} \mathrm{C}_{7} \mathrm{H}_{8} / \mathrm{L}$; the contaminant was completely removed from soil within $14 \mathrm{~h}$. Lee et al. (2012) reported that in a soil with $\mathrm{pH} 6.7$ and amended with $500 \mathrm{mg} \mathrm{C}_{7} \mathrm{H}_{8} / \mathrm{L}$ removal of the contaminant took approximately 10 days. The removal of toluene from the arable soil was similar to that described by Lee et al. (2012), while in the Texcoco soil it took only 3 days.

The two soils used in this experiment were selected as they are contrasting. On one hand, an extreme alkaline saline soil flooded irregularly with effluent that might contain hydrocarbons and on the other hand an arable soil never contaminated with hydrocarbons (Luna-Guido et al. 2000). These two contrasting soils allow us to determine if degradation of hydrocarbons would be affected by the different ecosystem characteristics. In this study, the removal of toluene was faster from the alkaline soil than from the arable soil. Different explanations are possible for this phenomenon. First, the microorganisms in the Texcoco soil metabolized the toluene more efficiently than those in the arable soil. However, it would be difficult to explain why microorganisms in the arable soil were less capable of removing toluene than those from the alkaline soil. Second, a higher microbial activity will stimulate the removal of a contaminant from soil. However, the emission of $\mathrm{CO}_{2}$, an indicator of microbial activity was larger from the arable soil than from the Texcoco soil, although the removal of toluene was larger from the latter than from the first. Third, the availability of the toluene in the arable soil was lower than in the alkaline soil so that the removal was lower in the first than in the latter. The bioavailability of toluene was indeed larger in the Texcoco soil than in the arable soil, as its removal was faster and the percentage mineralized larger in the first than in the latter. The bioavailability of a contaminant is affected by different soil characteristics. First, an increase in organic matter is known to decrease the removal of contaminants from soil as they might get fixed on it (Yang et al. $2010 \mathrm{~b}$ ). However, the soil organic matter was lower in the arable soil than in the alkaline soil. Second, clay particles are known to fix organic material rendering them unavailable for degradation. Davis and Madsen (1996) reported that an increase in the percentage of silt and clay in the soil increases the residence time of toluene, indicating that these two components adsorbed toluene reducing its bioavailability. However, the clay content was similar in the Texcoco and the arable soil. Third, a high salt content in soil is known to disperse soil particles and reduce the amount of soil aggregates thereby limiting the amount of organic material that can protected physically within the aggregates. Indeed, the EC of the Texcoco soil was higher than that in the arable soil and might thus have increased bioavailability and degradation of toluene.

Most of the toluene in the headspace was mineralized within 10 days. The amount of toluene in the headspace of flasks incubated with the arable soil was larger than in the alkaline soil. As such, more toluene volatilized from the arable than from the alkaline soil, although the removal of toluene was faster from the alkaline than the arable soil. Once again soil characteristics will define how much of the added toluene is fixed on the soil matrix and how much will volatilize. It appears, however, that the soil characteristics that controlled bioavailability were different from those that define volatilization. Voutsas et al. (2005) reported that the amount of water, organic matter content, porosity, vapor pressure, solubility of the contaminant, absorption coefficient, air flow, moisture and temperature are factors that control the volatility of an organic compound from soil. In this study, incubation conditions were similar for both soils. Consequently, soil water content, porosity, the coefficient of adsorption and organic matter content, defined the amount of toluene volatilized.

The organic $\mathrm{C}$ content was lower in the arable soil than in the alkaline soil although emission of $\mathrm{CO}_{2}$ was larger from the first than from the latter (Fig. 3a, b). The increase in emission of $\mathrm{CO}_{2}$ in soil amended with toluene compared to the unamended soil showed a lag of two days in both soils. As such the degradability of the soil organic matter was lower in the Texcoco soil than in the arable soil. The maize crop residue retained in the arable soil is easily mineralizable, but 
a) Texcoco soil

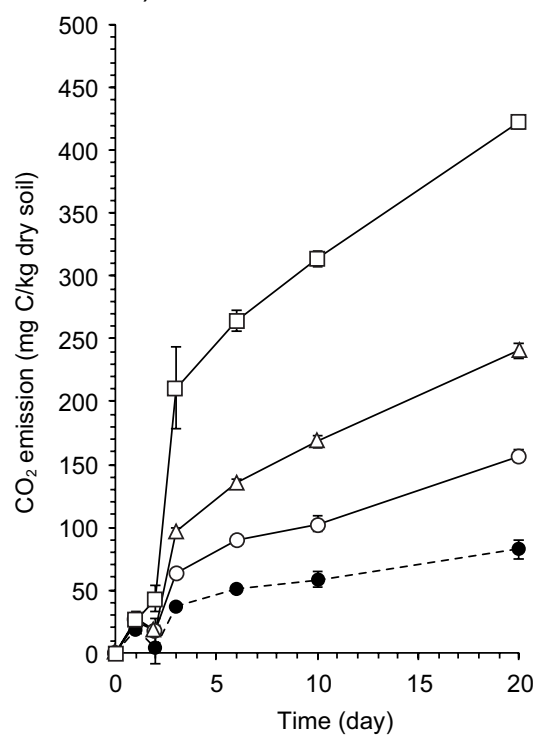

b) Otumba soil

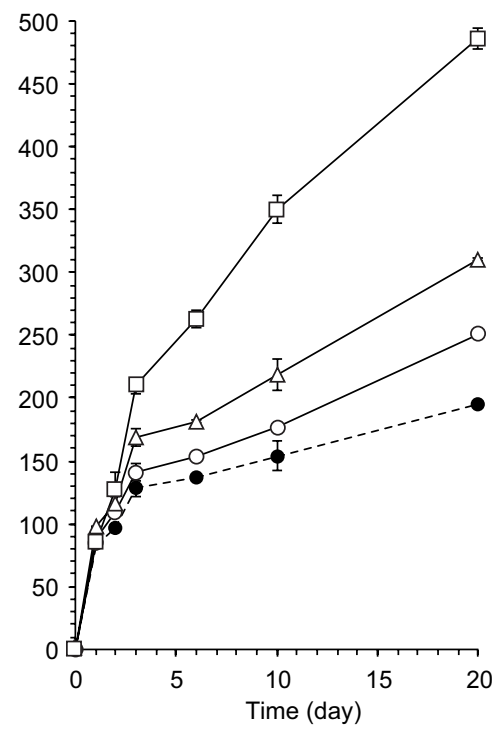

- Unamended soil -o-100 mg toluene/kg $\triangle-200 \mathrm{mg}$ toluene/kg $\square-500 \mathrm{mg}$ toluene/kg

Fig. 3. Emissions of $\mathrm{CO}_{2}$ ( $\mathrm{mg} \mathrm{C} / \mathrm{kg}$ dry soil) from a) unsterilized soil of the former Lake Texcoco and (b) the Otumba soil. Unamended soil $(\bullet)$ or soil amended with 100 $(\circ), 200(\Delta)$ or $500 \mathrm{mg}$ toluene/kg dry soil $(\square)$

the soil organic material in the Texcoco soil was more resistant to degradation. Considering no priming effect (Kuzyakov et al. 2000), then $60 \%$ of the toluene applied to the arable soil was mineralized, while $80 \%$ in the Texcoco soil after 20 days. Mineralization of easily decomposable organic material (toluene) was not inhibited in the Texcoco soil.

Tsao et al. (1998) found that nearly $56 \%$ of ${ }^{14} \mathrm{C}$-labelled toluene added to a sandy loam soil at $3 \mu \mathrm{l} / \mathrm{g}$ was mineralized within 4 weeks. Mineralization of toluene, considering no priming effect was faster in this study. Differences in mineralization rates between soils depend on soil characteristics, especially clay and silt content (Chung and Alexander 2002).

An increase in emission of $\mathrm{CO}_{2}$, which is the result of mineralization of the contaminant, was only apparent after 2 days. Consequently, there was a lag between the break-up of the aromatic ring and its mineralization. Zhang and Bouwer (1997) reported that a pre-equilibrated soil-water slurry amended with $200 \mathrm{mg} \mathrm{C}_{7} \mathrm{H}_{8} / \mathrm{L}$ showed a lag phase of 3 days. Similarly, Davis and Madsen (1996) mentioned a lag phase in the degradation of toluene applied at a concentration of $50 \mathrm{mg} / \mathrm{kg}$ in soil with $\mathrm{pH}$ of 5.4, 7.8 and 7.9. It can be hypothesized that the lag phase is a result of the absorption of toluene within the cells.
Once in the cells, toluene can be metabolized along eight different metabolic pathways (Jindrová et al. 2002). None of the pathways reported included extracellular decarboxylation reactions so the toluene must first be transported into the cell before being metabolized explaining the lag.

\section{CONCLUSIONS}

No abiotic process affected the concentration of toluene in soil. In the unsterilized soil, toluene was quickly removed independent from the amount applied. Within two days $73 \%, 59 \%$ and $69 \%$ was dissipated from the arable soil and $88 \%, 93 \%$ and $96 \%$ when 100, 200 or $500 \mathrm{mg} \mathrm{C}_{7} \mathrm{H}_{8} / \mathrm{kg}$ was applied, respectively. The removal of toluene was faster from the alkaline than from the arable soil. The mineralization of toluene as evidenced by an increase in emissions of $\mathrm{CO}_{2}$ showed a lag phase of two days compared to the decrease in the concentration of toluene. Considering no priming effect, then approximately $81 \%$ of the toluene added to the Texcoco soil and $62 \%$ in the Otumba soil was mineralized. Consequently, most of the toluene was removed from the soil and its effect on the environment will thus be limited. 


\section{REFERENCES}

Aguilar-Chávez A.R., Díaz-Rojas M., Cárdenas-Aquino M.R., Dendooven L. and Luna-Guido M.L. (2012). Greenhouse gas emissions from a wastewater sludge amended soil cultivated with wheat (Triticum spp. L.) as affected by different application rates of charcoal. Soil Biol. Biochem. 52, 90-95.

DOI: 10.1016/j.soilbio.2012.04.022

Bremner J.M. (1996). Nitrogen-total. In: Methods of soil analysis:chemical methods part 3. Soil Science Society of America Inc., (D.L. Sparks, Ed.). American Society of Agronomy, Inc., Madison, Wisconsin, USA, pp. 1085-1122.

Chung N. and Alexander M. (2002). Effect of soil properties on bioavailability and extractability of phenanthrene and atrazine sequestered in soil. Chemosphere 48 (1), 109-115.

DOI: $10.1016 / \mathrm{S} 0045-6535(02) 00045-0$

Daghio M., Vaiopoulou E., Patil S. A., Suárez-Suárez A., Head I. M., Franzetti A. and Rabaey K. (2016). Anodes stimulate anaerobic toluene degradation via sulfur cycling in marine sediments. Appl. Environ. Microbiol. 82 (1), 297-307. DOI: 10.1128/AEM.02250-15

Davis J.W. and Madsen S. (1996). Factors affecting the biodegradation of toluene in soil. Chemosphere 33 (1), 107-130. DOI: 10.1016/0045-6535(96)00152-X

Deziel N.C., Rull R.P., Colt J.S., Reynolds P., Whitehead T.P., Gunier R.B., Month S.R., Taggart D.R., Buffler P., Ward M.H. and Metayer C. (2014). Polycyclic aromatic hydrocarbons in residential dust and risk of childhood acute lymphoblastic leukemia. Environ. Res. 133, 388395. DOI: 10.1016/j.envres.2014.04.033

Dendooven L., Alcántara-Hernández R.J., ValenzuelaEncinas C., Luna-Guido M., Perez F. and Marsch R. (2010). Dynamics of carbon and nitrogen in an 'extreme' alkaline saline soil: A review. Soil Biol. Biochem. 42 (6), 865-877.

DOI: 10.1016/j.soilbio.2010.02.014

Fernández-Luqueno F., López-Valdéz F., Dendooven L., Luna-Suárez S. and Ceballos-Ramírez J.M. (2016). Why wastewater sludge stimulates and accelerates removal of PAHs in polluted soils?. Appl. Soil Ecol. 101, 1-4. DOI: 10.1016/j.apsoil.2016.01.013

Gee G.W. and Bauder J.W. (1986). Particle size analysis. In: Methods of soil analysis. Vol. I Physical and mineralogical methods (A. Klute, Ed.), American Society of Agronomy Madison, WI, USA, pp. 383-411.

Gui-Zhen W., Xin C., Bo Z., Zhe-Sheng W., Yun-Chao H., Hao-Bin C., Gao-Feng L., Zhi-Liang H., YongChun Z., Lin F., Ming-Ming W., Li-Wei Q., Yi C. and Guang-Biao Z. (2015). The chemokine CXCL13 in lung cancers associated with environmental polycyclic aromatic hydrocarbons pollution. eLife 4, e09419. DOI: $10.7554 /$ eLife.09419

Jenkinson D. and Powlson D.S. (1976a). The effects of biocidal treatments on metabolism in soil - I. Fumigation with chloroform. Soil Biol. Biochem. 8 (3), 167-177. DOI: 10.1016/0038-0717(76)90001-8

Jenkinson D.S. and Powlson D.S. (1976b). The effects of biocidal treatments on metabolism in soil-V: A method for measuring soil biomass. Soil Biol. Biochem. 8 (3), 209-213.

DOI: 10.1016/0038-0717(76)90005-5

Jindrová E., Chocova M., Demnerova K. and Brenner V. (2002). Bacterial aerobic degradation of benzene, toluene, ethylbenzene and xylene. Folia Microbiol. 47 (2), 83-93. DOI: 10.1007/BF02817664

Kuzyakov Y., Friedel J.K. and Stahr K. (2000). Review of mechanisms and quantification of priming effects. Soil Biol. Biochem. 32 (11-12), 1485-1498. DOI: 10.1016/S0038-0717(00)00084-5

Lee E.H., Park H. and Cho K.S. (2012). Biodegradation of methane, benzene, and toluene by a consortium MBT14 enriched from a landfill cover soil. J. Environ. Health 48 (3), 273-278.

DOI: $10.1080 / 10934529.2013 .726812$

Luna-Guido M.L., Beltrán-Hernández R.I., Solis-Ceballos N.A., Hernández-Chavez N., Mercado-García F., Olalde-Portugal V., Catt J.A. and Dendooven L. (2000). Chemical and biological characteristics of alkaline saline soils from the former lake Texcoco as affected by artificial drainage. Biol. Fert. Soils 32 (2), 102-108. DOI: $10.1007 / \mathrm{s} 003740000223$

Luna-Guido M.L., Vega-Estrada J., Ponce-Mendoza A., Hernández-Hernández H., Montes-Horcasitas M.C., Vaca-Mier M. and Dendooven L. (2003). Mineralization of ${ }^{14} \mathrm{C}$-labelled maize in alkaline saline soils. Plant Soil 250 (1), 29-38.

DOI: $10.1023 / \mathrm{A}: 1022865728953$

PEMEX (2016). Informe anual 2015. Petróleos Mexicanos. Informe. Ciudad de México, Mexico, 97 pp.

SAS (1989). Software: the SAS System for Windows versión 6.04. Statistical Analysis System Institute Inc., Cary, NC 25513, North Carolina, USA.

Shaheen S.M., Hooda P.S. and Tsadilas C.D. (2014). Opportunities and challenges in the use of coal fly ash for soil improvements - A review. J. Environ. Manage. 145, 249-267. DOI: 10.1016/j.jenvman.2014.07.005. 14

Song Y.F., Ou Z.Q., Sun T.H., Yediler A., Lorinci G. and Kettrup A. (1995). Analytical method for polycyclic aromatic hydrocarbons (PAHs) in soil and plants samples. Chin. J. Appl. Ecol. 6 (1), 92-96.

Tsao C.W., Song H.G. and Bartha R. (1998). Metabolism of benzene, toluene, and xylene hydrocarbons in soil. Appl. Environ. Microb. 64 (12), 4924-4929. 
Voutsas E., Vavva C., Magoulas K. and Tassios D. (2005). Estimation of the volatilization of organic compounds from soil surfaces. Chemosphere 58 (6), 751-758. DOI: 10.1016/j.chemosphere.2004.09.057

Woods A., Watwood M. and Schwartz E. (2011). Identification of a toluene-degrading bacterium from a soil sample through $\mathrm{H} 218 \mathrm{O}$ DNA stable isotope probing. Appl. Environ. Microbiol. 77 (17), 5995-5999.

DOI: 10.1128/AEM.05689-11

Yadav B.K., Shrestha S.R. and Hassanizadeh M. (2012). Biodegradation of toluene under seasonal and diurnal fluctuations of soil-water temperature. Water Air Soil Pollut. 223 (7), 3579-3588.

DOI: $10.1007 / \mathrm{s} 11270-011-1052-\mathrm{x}$

Yang Y., Tao S., Zhang N., Zhang D.Y. and Li X.Q. (2010a). The effect of soil organic matter on fate of polycyclic aromatic hydrocarbons in soil: A microcosm study. Environ. Pollut. 158 (5), 1768-1774.

DOI: 10.1016/j.envpol.2009.11.010
Yang Y., Zhang N., Xue M. and Tao S. (2010b). Impact of soil organic matter on the distribution of polycyclic aromatic hydrocarbons (PAHs) in soils. Environ. Pollut. 158 (6), 2170-2174.

DOI: 10.1016/j.envpol.2010.02.019

Zhang W.X. and Bouwer E.J. (1997). Biodegradation of benzene, toluene and naphthalene in soil-water slurry microcosms. Biodegradation 8 (3), 167-175.

DOI: 10.1023/A:1008259511282

Zhang H., Pennisi S.V., Kays S.J. and Habteselassie M.Y. (2013). Isolation and identification of toluenemetabolizing bacteria from rhizospheres of two indoor plants. Water Air Soil Pollut. 224 (9), 1648.

DOI: $10.1007 / \mathrm{s} 11270-013-1648-4$ 